\title{
IDEAS THAT MATTER: PARTING THOUGHTS ON CHARLES BEARD ON THE 100TH ANNIVERSARY OF AN ECONOMIC INTERPRETATION
}

\author{
Jessica K. Lowe*
}

Charles Beard's work presents an irony. On the one hand, Beard's An Economic Interpretation is known to historians, especially historians of America, as the epitome of a certain type of work: one that sees "interests"-or more precisely, economic interest - as the primary human motivation in history. ${ }^{1}$ Beard's book, although discarded in many of its particulars, is still influential for its perspective: an unrelenting insistence that the American founders were motivated not by lofty ideals (or even not-so-lofty ones) but by their certificates and bonds and pocketbooks; as G. Edward White puts it, Beard "invited the conclusion that interests drove ideas." ${ }^{2}$ On the other hand, despite this emphasis on interest, Beard was, like his Progressive contemporaries, a bit of an idealist himself. As Ajay Mehrotra reminds us, Beard saw the goal of all thought as a search for "truth"; while he certainly ravaged the "crowned constitution and

* Associate Professor of Law, University of Virginia School of Law. Thank you to the Law School and to the Miller Center for their generous co-sponsorship of this 2013 conference, commemorating the one-hundredth anniversary of Charles Beard's $A n$ Economic Interpretation of the Constitution, and to my co-organizer Mark Graber for his great ideas and scholarly generosity. I would also like to thank all of the participants of the symposium-Charles McCurdy, Clyde Barrow, Jonathan Gienapp, Ajay Mehrotra, Richard Drake, Adrian Vermeule, Hank Chambers, Risa Goluboff, Melvin Urofksy, Michael Caires, Stephen Feldman, G. Edward White, Mary Anne Case, Saul Cornell, Bartholomew Sparrow, Shannon Bow O'Brien, and Gerald Baliles. Risa Goluboff, Hendrik Hartog, Peter Onuf, Cynthia Nicoletti, Anne Twitty, and G. Edward White provided valuable feedback on a draft of this essay, and Dael Norwood gave especially helpful thoughts on historiography.

1. Jonathan Gienapp, Using Beard to Overcome Beardianism: Charles Beard's Forgotten Historicism and the Ideas-Interests Dichotomy, 29 CONST. COMMENT. 367, 371 (2014).

2. G. Edward White, Charles Beard \& Progressive Legal History, 29 CONST. COMMENT. 349, 352 (2014). 
its halo," Beard did so because, in his words, "the seeker of truth must be fearless." ${ }^{3}$

This irony evokes the full significance of An Economic Interpretation. The book's brilliance is not in its writing-in its repetitive analysis or in its catalogue of persons and personaltybut rather in its moral force-its muckraking ${ }^{4}$ - which casts aside popular and scholarly constitutional veneration to expose a rank, self-interested underbelly. Beard, as Richard Drake relates, was spurred on by his experiences at Oxford and deeply interested in the education of and support for the working man; he considered pursuing a career as an activist as well as a scholar, and ultimately "sought to do both." As a scholar, Beard was indignant indignant about constitutional veneration, yes, but even more about the way the "sacred" Constitution had been made a cover for "every great national sin - from slavery to monopoly." If the Constitution was the national temple, Beard was turning over its moneychangers' tables. This radical speech act, rather than the content of the work, is his signal contribution to the historiography of the United States.

After the publication of An Economic Interpretation in 1913, a full generation of historians debated Beard's accuracy. They sifted through the framers' yellowed account books, local court records, and centuries-old ruminations on state, government, and politics to dispute his claims, arguing about the inaccuracy of his reduction of their work and ideas to mere self-interest. ${ }^{7}$ By 1968 , as White relates, historian Richard Hofstadter could describe Beard's legacy as an "imposing ruin." ${ }^{8}$ Beard and his Progressive critique of the Constitution (along with the Progressive ideas of "science" that shaped it) yielded ground to a new generation of historians, focused on ideology and the distinctively "republican" worldview of the founding generation, one fused from a conglomeration of English sources, Enlightenment and religious thought, and colonial experience, and one which put forth its own

3. Ajay K. Mehrotra, Charles A. Beard \& the Columbia School of Political Economy: Revisiting the Intellectual Roots of the Beardian Thesis, 29 CONST. COMMENT. 475, 484 (2014).

4. White, supra note 2, at 360.

5. Richard Drake, Charles Beard \& the English Historians, 29 CONST. COMMENT. 313, 315 (2014).

6. Mehrotra, supra note 3, at 497 (quoting Beard).

7. See, e.g., ForRest MCDONALD, We The PeOPle: The ECONOMIC ORIGINS OF THE CONSTITUTION (1958).

8. White, supra note 2, at 349 . 
imperatives for behavior, like virtue and self-restraint. ${ }^{9}$ On the whole, the republican worldview that this "ideological school" portrayed was a different "mental world," as Jonathan Gienapp puts it, from our own, one which scholars working in this vein saw themselves as translating. ${ }^{10}$ In the process, they shattered the notion that a universality of motivations united the American founders with subsequent generations - and that those motivations could be reduced to a single factor, rational selfinterest.

Of course, despite long hegemony, the ideological school itself came under threat. One attack came from neo-progressives, developing Beardian themes and exploring the framers' economic motives; another focused, also in a Beardian vein, on the relationship between the Constitution and slavery. ${ }^{11}$ But the principal challenge was from the turn towards broader, transnational history-from new, self-consciously distinct paradigms that emphasized empire and the Atlantic world, or international history. ${ }^{12}$ Eventually the point of studying the era was to embed America in something broader; to look past ideology to questions about the movement of persons, economies, ideas, and political forms across space; studying the Constitution - particularly as a peculiarly American subject - was disfavored unless carefully contextualized by Atlantic themes. In other works, the Constitution fared somewhat better,

9. See Daniel T. Rodgers, Republicanism: The Career of a Concept, 79 J. AM. HIsT. 11-38 (1992). This spawned a related argument about whether early America was shaped more by these "republican" ideas or by the "liberal" ideas of John Locke. See, e.g., JOYCE ApPleby, Capitalism And a New Social ORder: The Republican Vision of the 1790s (1984).

10. Gienapp, supra note 1, at 369-70.

11. See, e.g., WoOdy Holton, UnRUly AMERICANS AND THE ORIGINS OF THE Constitution (2007); George Van Cleve, A Slaveholders' Union: Slavery, POLITICS, AND THE CONSTITUTION IN THE EARLY AMERICAN REPUBLIC (2010).

12. See, e.g., ATLANTIC History: A CRITICAL APPRAISAL (Jack P. Greene \& Philip D. Morgan eds., 2009); DAVID C. HENDRICKSON, PEACE PACT: THE LOST WORLD OF THE AMERICAN FOUNDING (2003); DAVID ARMITAGE, THE DEClaration OF INDEPENDENCE: A GLOBAL HISTORY (2007).

13. See, e.g., Laurent Dubois, A Colony of Citizens: Revolution \& Slave EMANCIPATION IN THE FRENCH CARIBBEAN, 1787-1804 (2004); MAYA JASANOFF, LIBERTY'S EXILES: AMERICAN LOYALISTS IN THE REVOLUTIONARY WORLD (2011); THEORIES OF EMPIRE: 1450-1800 (David Armitage ed., 1998). As Daniel Hulsebosch puts it, the study of the American Constitution became associated, negatively, with the old "Whig history," which "celebrated freedom"; "Constitutional history in particular," Hulsebosch writes, "became a story of the growth of American liberty." DANIEL HulsebosCH, CONSTITUTING EMPIRE: NEW YORK AND THE TRANSFORMATION OF CONSTITUTIONALISM IN THE ATLANTIC WORLD, 1664-1830 4 (2005). 
particularly in studies on state-building and, of course, in Pauline Maier's beautiful, meticulous history of the ratification effort. ${ }^{14}$

This is the historiographical world in which we look anew at Beard's great work. And that work has plenty of flaws. Beard's modernist assumptions, White concludes (echoing the predominant scholarly opinion), "fit poorly with those of the founding generation." 15 And Adrian Vermeule further reminds us that while Beard shaped generations of history, constitutional law scholars barely noticed him in the first place-there is a radical disconnect, Vermeule suggests, between constitutional history and constitutional law. ${ }^{16}$ On the other hand, Michael Caires reports that although Beard's An Economic Interpretation has been largely discredited, his work on the Civil War has fared better; in The Rise of American Civilization (1927), Beard and his wife Mary Ritter Beard argued, according to Caires, that the "real significance of the Civil War was not found in the war itself, but in the economic transformation of the North," and this remains the "bedrock" of historians' views of the period. ${ }^{17}$ Bartholomew Sparrow and Shannon Bow O'Brien defend even Beard's constitutional thought, but lament that his analysis largely omitted the mass of propertyless whites, which would have made the patterns he finds even starker; Stephen Feldman argues that Beard is relevant to modern ideas of constitutionalism. ${ }^{18}$ Finally, Beard also lingers, according to Jonathan Gienapp, in another way-his focus on "interest" as a motivating force has left an enduring, perhaps unfortunate, interest-ideology cleft in historical thinking. ${ }^{19}$

Of course, Beard's legacy also remains salient for its attack on constitutional veneration, and a useful corrective to tendencies to sacralize that document and the founding. As Mary Ann Case

14. Pauline Maier, Ratification: The People Debate the Constitution, 1787-1788 (2010). For an example of a history focused on state building, see MAX M. EDLING, A REVOLUTION IN FAVOR OF GOVERNMENT: ORIGINS OF THE U.S. CONSTITUTION AND THE MAKING OF THE AMERICAN STATE (2003).

15. White, supra note 2, at 365.

16. Adrian Vermeule, Beard \& Holmes on Constitutional Adjudication, 29 CONST. COMMENT. 457, 463 (2014).

17. Michael T. Caires, Rethinking the Second American Revolution: Legal Tender and National Banking in the Civil War Era, 29 CONST. COMMENT. 511, 511 (2014).

18. Bartholomew Sparrow \& Shannon Bow O'Brien, Pulling Punches: Charles Beard, the Propertyless, and the Founding of the United States, 29 CONST. COMMENT. 409, 409 (2014); Stephen M. Feldman, The Interpretation of Constitutional History, or Charles Beard Becomes a Fortuneteller (with an Emphasis on Free Expression), 29 CONST. COMMENT. 323, 339-42 (2014).

19. Gienapp, supra note 1, at 371 . 
asserts, the sacred Constitution against which Beard railed is alive and well today, perhaps even resurgent. ${ }^{20}$ Generations of Americans have, as my forthcoming work discusses, emphasized our nation's sacred political text, comparing it and its interpretation to the Bible. ${ }^{21}$ Recently, former House Majority Whip Tom Delay even went further when he asserted, "God . . . wrote the Constitution."22 Beardian scholarship calls this sacredness into question in a vehement way-one that, as Saul Cornell notes, is accepted, at least in its mild forms, by most historians. ${ }^{23}$

But questioning the sacred Constitution does not translate directly into post-modern cynicism, either. Recognizing the flawed nature of our constitutional endeavor does not have to mean turning one's back to all claims of justice, fairness, or truth. After all, if Beard's Constitution was economics, his history was still science (in its broad sense) with its associated Progressive optimism about the discipline. ${ }^{24}$ Some of that sense of historical science has, of course, peaked and washed away with the tide of time. But where science itself is no longer an accurate descriptor, the search for truth, if a mangled one, still is. In this sense, the craft of history itself still gains its force partly through the same mechanism that made Beard great-those of dispute and corrective. In questioning a sacred national past, and the narratives constructed by other scholars, we historians take our own measure, and that of those who have gone beforerecognizing the culturally limited nature of their aims and claims, while still learning what they have to teach us, for good and for bad.

Even while noting the limits of our own perspectives and the biases of our interests (scholarly, if not economic), history somehow stops short of being a fully postmodern discipline, made

20. Mary Anne Case, The Ladies? Forget About Them. A Feminist Perspective on the Limits of Originalism, 29 CONST. COMMENT. 431, 448 (2014).

21. Jessica K. Lowe, Sacred Texts, Sacred Interpretation: How America Became a Nation of the Word (work in progress) (on file with the author).

22. Shandee Ashtari, Tom Delay Claims God "Wrote the Constitution," HufFington Post (Feb. 29, 2014).

23. Saul Cornell, Conflict, Consensus \& Constitutional Meaning: The Enduring Legacy of Charles Beard, 29 CONST. COMMENT. 383, 383 (2014).

24. See White, supra note 2, at 106-08 for a good discussion of Progressivism and the legal historiography. Of course, Beard rejected the idea that history was science in its narrow sense, relatable to "physics or biology," but affirmed the scientific method as "precious and indispensable," problematic only when "this method, a child of the human brain, is exalted into master and tyrant." Charles A. Beard, Written History as an Act of Faith, 39 AM. HisT. REV. 219, 225, 227. 
up merely of our own stories about ourselves, camouflaged by the past. It is that, of course-stories about, in some ways, ourselves as well as our subjects - but it is also more. There is, among historians, the sense that what we seek is somehow truth, however limited and fragile, buried within archival boxes of dusty letters and long-forgotten tomes; that there is something accessible, something real, even as we enter into the foreign country of the past. Even amidst the clamors of vehement historiographical disputes, the vectors of contrasting argument still point to something - something real, whose realness is intuitively thought to be revealed through layers and layers of modern scholarly argumentation and dispute. ${ }^{25}$ As Beard himself put it, history "contains all the exactness that is possible and all the bewildering problems inherent in the nature of thought and the relation of thinker to the thing thought about."26 At the same time, the historian retains "at bottom a conviction that something true can be known about the movement of history." 27

So where does Beard's work leave us? Perhaps, in some ways, it reminds us that scholarship can be both brilliant and wrong. But that slightly misstates it. Because even where Beard is wrong, there is something about the book's orientation, its protest, that is also profoundly right. Not because bare economic self-interest is a universal, timeless motivator-most historians soundly reject such a notion, and Gienapp's reminder that conceptions of "selfinterest" at any given historical moment are themselves a product of culture is a helpful modification. ${ }^{28}$ But Beard's rightness is something else, something that might just be even bigger than the ideology/interest divide. After all, scholarly protest, like its political counterpart, is about more than the isolated substance of its position, taken on its own terms-rather, it is also about the very act of critique, and the relationship of the critique to that which is being critiqued. It's about the world the protest speaks to-the current world of scholars and readers and even thinkers of history-as well as the historical world that it speaks about. To use the language of Beard's time, history is both a science and a moral force, fact but also symbol. Historical truth, in other words, is multivalent.

25. See, e.g., Barbara Young Welke, "Glimmers of Life": An Interview with Hendrik Hartog, 27 LAW \& HIST. REV. 629 (2009).

26. Beard, supra note 24, at 219-20.

27. Id. at 226

28. Gienapp, supra note 1, at 372 . 
Beard's brilliant book spoke powerfully about his own time's interpretation of the past, and challenged its own subterfuge as well as that of the founders. Beard, as Drake observes, "had left England with a cause, and it would keep him going at his writing desk for a lifetime." ${ }^{29}$ His achievement-and those of historians after him - is greater than what Vermeule proffers, that of serving as an "expert witness about constitutional politics." ${ }^{30}$ Historians may indeed do that - after all, we'll take all the relevance we can get-but Beard himself demonstrates that they can also do much more. Beard's work was directed not to the courts alone, but to the world. He took the Constitution back to the people, at least in some ways, by debunking its façade of neutrality and sacredness. His work shattered-or at least attempted to-complacency and confronted hypocrisy, and had, as Richard Hofstadter later put it, "profound and decisive importance." ${ }^{31}$ Generations before critical legal scholars saw law as entrenched domination, Beard's critique anticipated their claims, warning against the Constitution's supposed neutrality. ${ }^{32}$ As White posits, Beard's real critique wasn't merely that interests governed politics - all Progressives thought that-but rather focused on indicting those political actors for their resistance to "leveling pressures for change."

Whatever the motives of the Constitution's framerseconomic bonds or social ones, perceptions of their own interest or perceptions of republican communal interests-Beard's insistence on their limitations is critical. Beard may not have shown up directly in constitutional law scholarship or court opinions, in the form of citations or quotations, but his critique deeply shaped our perception of that document-ironically, our ideas. (On the other hand, maybe his shaping of ideas was not ironic at all, since it was at ideas that Beard took aim.) Beard seized on the past to make a point about the present-and, as he did so, he implicitly pointed out that those who claimed pure historical study or legal science were doing so as well, but with less forthrightness. At the same time, Beard deconstructed not merely for deconstruction's sake, but with the radical moral end of social change in mind. ${ }^{34}$

29. Drake, supra note 5, at 322.

Vermeule, supra note 16 , at 471.

White, supra note 2, at 350.

See Robert W. Gordon, Critical Legal Histories, 36 STAN. L. REV. 57 (1984).

White, supra note 2, at 363.

Drake, supra note 5, at 315. 
In the end, perhaps Beard's activist jumble of past and present offers up a reminder not only about the importance of writing what is sometimes called a "usable past," history that matters for today, but also reminds us that we live in a usable past as well. Institutions and texts laid down by people far removed from the present still hold significant sway. Recognizing the uses and authorities of this past, alive and thriving in our midst, allows us in turn to move toward the future. We do this not by merely dismissing all that has come before, but through confrontation and corrective, continuing the flawed but important tripping towards truth and justice-the journey upon which Beard so fervently insisted. 